\title{
A Study of Financial Integration and Optimal Diversification Strategy in ASEAN Equity Markets
}

Peter Hwang

Department of International Business, National Taiwan University, Taipei, Taiwan

Romora Edward Sitorus

Sampoerna School of Business, Universitas Siswa Bangsa Internasional, Jakarta, Indonesia

\begin{abstract}
This paper examines the country and industry effects on the cross-sectional variance of firms' equity return in the Association of Southeast Asian Nations (ASEAN) member countries. Using the model developed by Heston and Rouwenhorst (1994), this article covers five ASEAN countries and ten industries. We find that pure country effects are, on average, more important than pure industry effects in explaining equity return variation of ASEAN firms. In terms of portfolio diversification strategies in ASEAN, our results show that country diversification is a more effective strategy for risk management than industry diversification. We also discuss the impacts of subprime mortgage crisis on ASEAN countries and industries.
\end{abstract}

\footnotetext{
* Corresponding Author: Peter Hwang; Department of International Business, National Taiwan University, No.1, Sec. 4, Roosevelt Rd., Taipei City 106, Taiwan (R.O.C.); Tel: +886 233664991, Fax: +886 223627203; E-mail: fbahjh@ hotmail.com.

Co-Author: Romora Edward Sitorus; Sampoerna School of Business, Universitas Siswa Bangsa Internasional, Mulia Business Park, Jl. MT. Haryono Kav. 58-60, Jakarta Selatan, 12780; Indonesia; Tel: +62 82125636926, Fax: +62 217942330; E-mail: romora.edward@usbi.ac.id.
}

Acknowledgements: We are very grateful to conference and seminar participants at World Finance Conference 2012 (Beijing) and 8th Conference on Risk, Banking and Financial Stability - JFS for the helpful comments and suggestions. 
JEL Classifications: F36, G11, G15

Key words: Financial Integration, Industrial Structure, Emerging Markets, Diversification

\section{Introduction}

The case for international diversification has been built on the low correlations between national equity markets. Grubel (1968), Levy and Sarnat (1970), and Solnik (1974) show evidence of low correlations between index returns in different countries and suggest that benefit of international diversification outweigh its costs.

Following the notion of international diversification, a fundamental starting point for global equity managers has been the selection of country (country effects). This focus arose out of numerous studies that established country effects as the major influence on equity returns in mature markets (Heston and Rouwenhorst 1994, Griffin and Karolyi 1998).

The relative importance of the country effect has been challenged over time. Lessard (1974) was the first to document the differences in industrial composition (industrial effects) as an important effect explaining the variation in country index return. More recent research (Baca et al. 2000, Cavaglia et al. 2000) concluded that the importance of industrial effects has grown to exceed those of country effects.

Most previous studies about country and industry effects have used the data of developed countries and one cannot be sure whether their results apply to emerging markets. Previous studies (Harvey 1995, Bekaert and Harvey 1995, 1997, 2000, Bekaert et al. 2001) argued that return of emerging markets has different characteristics from the ones in developed markets.

Our article revisits the relative importance of country and industry effects and their changes over time in the context of the emerging markets of ASEAN-5 (Indonesia, Malaysia, Philippines, Singapore, and Thailand). The economic regionalism in ASEAN has been greatly revived especially since Asian Financial Crisis, 1997 1998, that devastated the economies of most ASEAN countries. The crisis has prompted ASEAN countries to realize the importance of strengthening regional economies in a concerted way. Increased links among ASEAN capital markets, the establishment of trading blocs between ASEAN countries and the increasingly global nature of business 
would influence the relative importance of country and industry effects in ASEAN equity returns. The integration efforts could distort national borders and, other things being equal, diminish the significance of country effect and industry effects. ASEAN integration initiatives may induce co-movement among ASEAN member countries and force ASEAN portfolio managers to abandon international diversification based on country-based allocation strategy. ASEAN integration blurred the difference among ASEAN equity markets and may even lead to unified ASEAN market in which country allocation becomes less important.

In light of these trends, it is interesting to examine how international investment managers continue to find diversification opportunities and excess returns in the ASEAN markets.

Although ASEAN regionalization initiatives are powerful forces to amplify the comovement of ASEAN equity market returns, many factors that differentiate the ASEAN markets are still in place. Despite the fact that many ASEAN companies have dispersed their production and sales activities across ASEAN in recent years, domestic market remains dominant and important for those companies. In addition, great differences persist in ASEAN political systems, tax and legal systems, institutional development and socio demographic situations. One that is unaffected by the process of ASEAN integration, is the different industry mixes in each national equity markets. For example, the equity market in Thailand is heavily weighted toward cyclical industries, such as consumer services and technology industries, whereas in the Malaysian equity market, consumer goods companies, are largely unaffected by the business cycle.

Our study shows that country effect still dominates industry effect in explaining equity return variation of ASEAN firms during the period 2001 2011. This result, however, may change over time because industry effect has grown in importance in recent years. The potential explanation of country effect dominance over industry effect is twofold: First, the existence of home bias by investors. Historically, investors prefer to invest in their domestic stock market because they are more informed and optimistic about the future performance of the market (French and Poterba 1991, Cooper and Kaplanis 1994, Tesar and Werner 1995, Flavin 2004). In addition to that, investors also tend to overweight certain international markets in their portfolio holdings, such as those that are geographically close, and have common language or culture with investor (Chan et al. 2005, Leuz et al. 2010, Anderson et al. 2011, Fedenia et al. 2013). Second, the asymmetry of responses to fundamental economic shocks. For instance, each country in ASEAN may have specific fiscal or monetary policy to deal with national or global 
shocks because of their institutional differences. Thus, diverse country sensitivities to economic shocks may result in segmentation between countries or market (Karolyi and Stulz 1996, Ammer and Mei 1996, Flavin 2004).

Our research extends the existing literature in several ways. (i) Our dataset cover ASEAN-5 countries using monthly data for 227 companies, allowing us to examine more rigorously the changes of the country and industry effects in ASEAN equity markets. Most studies studying the relative importance of country and industry effects focus on developing countries instead of emerging markets. Eun and Lee (2010), for instance, investigate the effect of country and industry effect as the driver of risk-return characteristics convergence, using a sample of 17 developed stock markets. Other similar studies, such as Bekaert et al. (2009) and Eiling et al. (2012) also concentrate on 23 developed markets and seven major developed market (Canada, France, Germany, Italy, Japan, UK, and US), respectively.

(ii) We investigate the impact of the ASEAN regionalization initiatives and subprime crisis on the ASEAN country-industry decomposition. Using rolling 12-month average of country and industry effect, this study could examine how both country and industry effects have changed over time, particularly when regionalization effort intensifies and great economic shocks occurs. Our paper follows similar methods with Ferreira and Gama (2005) that use backward 12-month moving averages trend and Marcelo et al. (2013) which utilize 52-week moving average Mean Absolute Deviation (MAD).

(iii) We use firm-level data rather than the industry index data used in much of this stream of research. The usage of firm-level data allow us to get longer sample period compared to previous literatures, such as Roll (1992) that use daily data of country indexes from April 1988 through March 1991 and Griffin and Karolyi (1998) that employ Dow Jones World Stock index data which are available only for a short period between 1992 1995.

(iv) We utilize a rather more aggregated industry classification than in earlier studies. We argue that an excessively fine classification will involve arbitrary allocations of multi-activity firms to specific sectors. This classification problem is particularly important in emerging equity markets, where conglomerates are more prevalent, than in the major industrial countries. In regard to this, Griffin and Karolyi (1998) documents that it is better to have narrow industry classification to prevent loss of information about the cross-sectional variation of returns due to industry effects, i.e., some classifications may have very few constituents.

In the context of ASEAN-5 equity portfolio, this article investigates, (i) the relative 
importance of the country and the industry effects and its changes over time, (ii) the impact of industries on the variance of ASEAN country index and vice versa, and (iii) the economic implications of the country and industry effects to portfolio managers.

The rest of the article is organized as follows. Section II describes the data we use. Section III delineates the methodology, and results appear in Section IV. We offer the conclusions in Section V.

\section{Data Description}

The sample includes monthly total returns for all firms in the Datastream Global Equity indices of ASEAN-5 countries (Indonesia, Malaysia, Philippines, Singapore, and Thailand) from March 2001 to August 2011. We exclude other ASEAN countries, such as Brunei Darussalam, Cambodia, Laos, Myanmar, and Vietnam because their stock market data is neither available nor sufficient. Moreover, this study utilizes ten industry classifications because an excessively fine classification may create arbitrary allocations of multi-activity firms to particular sectors. Thus, in emerging markets, where many firms are conglomerates, a very narrow industrial classification can be problematic. Thus, the final sample consists of 227 companies with complete return history over the sample period. Our focus of a ten-year period already represents a substantial effort compared to the cross-sectional analysis of the related literatures. The firms are assigned to one of ten Datastream global market industry categories, based on Industry Classifications Benchmark (ICB) jointly created by FTSE and Dow Jones.

Table 1, Panel A shows that the industrial composition of country indices, as well as the geographical distribution of industries based on the number of firms. Panel A shows that most firms belong to one of four sectors: financials, industrial, consumer goods, and consumer services. Based on ICB, the consumer services sector consists of several subsectors such as retail, media, and travel and leisure. The examples of retail subsector are food and drug retailers, apparel retailers, and home improvement retailers. Media subsector covers broadcasting, entertainment, and media agency publishing. Moreover, travel and leisure subsector includes airlines, hotels, restaurants, and bars industries.

The number of firms in technology, healthcare, and utilities are relatively small. Not all countries have firms in technology sector. Indonesia, Malaysia, and Philippines 
are not represented in technology sector. Utility and consumer services tend to be concentrated in Malaysia whereas many consumer goods equities can be found in Indonesia. Financial sector dominates the equity index in our ASEAN sample, where more than $30 \%$ of all firms in Indonesia, Philippines, Singapore, and Thailand are in the finance sector. Slightly less than a quarter of the Malaysia firms are in the financial sector.

Table 1, Panel B gives the value weight of country and industry market capitalization measured as the percentage of the total capitalization of the ASEAN-5 markets. The overall market capitalization of the sample is 1,109,316 million dollars. The number of Singapore firms make up a quarter of the total number of firms but dominate almost $40 \%$ of the market capitalization of the sample. Malaysia makes up $27.3 \%$ of total market capitalization, followed by Thailand (13.3\%), Indonesia (12.7\%), and Philippines (7\%). Telecommunication stocks which make up less than $4.41 \%$ of the total number of firms in the sample, account for $14.38 \%$ of the market capitalization. Whereas, Consumer Goods which make up $17.6 \%$ of total number of firms in the sample, only account for less than $13 \%$ of total market capitalization. 
Table 1. Industry and Country Composition of Equity Indices

\section{A. Number of firms by country and industry}

\begin{tabular}{|l|c|c|c|c|c|c|}
\hline \multirow{2}{*}{ Industry } & \multicolumn{7}{|c|}{ Country } \\
\cline { 2 - 7 } & Indonesia & Singapore & Malaysia & Philippines & Thailand & ASEAN-5 \\
\hline Oil and Gas & 0 & 3 & 5 & 1 & 2 & 11 \\
Basic Materials & 3 & 1 & 2 & 2 & 3 & 11 \\
Industrials & 4 & 13 & 12 & 8 & 4 & 41 \\
Consumer Goods & 10 & 7 & 16 & 4 & 3 & 40 \\
Healthcare & 1 & 2 & 1 & 0 & 1 & 5 \\
Consumer Services & 0 & 8 & 12 & 2 & 6 & 28 \\
Telecommunications & 2 & 1 & 2 & 3 & 2 & 10 \\
Utilities & 0 & 0 & 4 & 2 & 2 & 8 \\
Financials & 9 & 19 & 15 & 15 & 13 & 71 \\
Technology & 0 & 1 & 0 & 0 & 1 & 2 \\
\hline Total & $\mathbf{2 9}$ & $\mathbf{5 5}$ & $\mathbf{6 9}$ & $\mathbf{3 7}$ & $\mathbf{3 7}$ & $\mathbf{2 2 7}$ \\
\hline
\end{tabular}

B. Weights in the ASEAN-5 value weighted market

\begin{tabular}{|l|c|c|c|c|c|c|}
\hline \multirow{2}{*}{ Industry } & \multicolumn{7}{|c|}{ Country } \\
\cline { 2 - 8 } & Indonesia & Singapore & Malaysia & Philippines & Thailand & ASEAN-5 \\
\hline Oil and Gas & 0.00 & 2.34 & 1.66 & 0.16 & 1.56 & 5.73 \\
Basic Materials & 1.10 & 0.14 & 0.26 & 0.11 & 0.78 & 2.39 \\
Industrials & 1.16 & 7.22 & 4.38 & 1.08 & 1.86 & 15.70 \\
Consumer Goods & 4.43 & 2.25 & 4.18 & 0.82 & 0.72 & 12.41 \\
Healthcare & 0.17 & 0.20 & 0.03 & 0.00 & 0.12 & 0.51 \\
Consumer Services & 0.00 & 5.04 & 3.22 & 0.24 & 1.02 & 9.52 \\
Telecommunications & 2.92 & 5.80 & 2.34 & 1.82 & 1.49 & 14.38 \\
Utilities & 0.00 & 0.00 & 3.69 & 0.31 & 0.51 & 4.51 \\
Financials & 3.01 & 16.32 & 7.55 & 2.49 & 4.70 & 34.08 \\
Technology & 0.00 & 0.30 & 0.00 & 0.00 & 0.48 & 0.78 \\
\hline Total & $\mathbf{1 2 . 7 9}$ & $\mathbf{3 9 . 6 1}$ & $\mathbf{2 7 . 3 2}$ & $\mathbf{7 . 0 3}$ & $\mathbf{1 3 . 2 5}$ & $\mathbf{1 0 0 . 0 0}$ \\
\hline
\end{tabular}

(Note) Industrials sector consists of construction, materials, industrial goods, and industrial services. Moreover, the consumer services sector contains several subsectors, such as: retail, media, and travel and leisure. 


\section{Table 2. Summary Statistics}

\section{A. By Country}

(monthly data 2001 2011)

\begin{tabular}{|l|c|c|c|c|c|c|c|}
\hline \multirow{2}{*}{ Country } & \multirow{2}{*}{ Mean } & \multirow{2}{*}{$\begin{array}{l}\text { Standard } \\
\text { Deviation }\end{array}$} & \multicolumn{5}{|c|}{ Correlations } \\
\cline { 5 - 8 } & & & INA & SING & MAY & PH & THAI \\
\hline Indonesia (INA) & $\mathbf{0 . 9 7}$ & $\mathbf{4 . 6 6}$ & 1 & 0.71 & 0.63 & 0.63 & 0.69 \\
\hline Singapore (SING) & $\mathbf{0 . 4 3}$ & $\mathbf{3 . 0 8}$ & & 1 & 0.73 & 0.67 & 0.71 \\
\hline Malaysia (MAY) & $\mathbf{0 . 4 5}$ & $\mathbf{2 . 2 1}$ & & & 1 & 0.64 & 0.56 \\
\hline Philippines (PH) & $\mathbf{0 . 6 4}$ & $\mathbf{3 . 3 9}$ & & & & 1 & 0.65 \\
\hline Thailand (THAI) & $\mathbf{0 . 6 8}$ & $\mathbf{3 . 3 3}$ & & & & & 1 \\
\hline
\end{tabular}

\section{B. By Industry}

(monthly data 2001 2011)

\begin{tabular}{|l|c|c|c|c|c|c|c|c|c|c|c|c|}
\hline \multirow{2}{*}{\multicolumn{1}{c|}{ Industry }} & \multirow{2}{*}{ Mean } & \multirow{2}{*}{$\begin{array}{l}\text { Standard } \\
\text { Deviation }\end{array}$} & \multicolumn{10}{|c|}{ Correlations } \\
\cline { 3 - 11 } & & OG & BM & IND & CG & H & CS & T & U & F & TEC \\
\hline Oil and Gas (OG) & $\mathbf{0 . 7 3}$ & $\mathbf{3 . 2 9}$ & 1 & 0.67 & 0.8 & 0.7 & 0.67 & 0.65 & 0.66 & 0.52 & 0.75 & 0.52 \\
\hline Basic Materials (BM) & $\mathbf{1 . 2 5}$ & $\mathbf{5 . 4}$ & & 1 & 0.82 & 0.79 & 0.71 & 0.7 & 0.68 & 0.54 & 0.77 & 0.66 \\
\hline Industrials (IND) & $\mathbf{0 . 6 9}$ & $\mathbf{2 . 7 1}$ & & & 1 & 0.89 & 0.78 & 0.89 & 0.78 & 0.72 & 0.92 & 0.66 \\
\hline Consumer Goods (CG) & $\mathbf{0 . 9}$ & $\mathbf{2 . 9 7}$ & & & & 1 & 0.78 & 0.79 & 0.78 & 0.69 & 0.83 & 0.59 \\
\hline Healthcare (H) & $\mathbf{0 . 9 2}$ & $\mathbf{3 . 3 6}$ & & & & & 1 & 0.71 & 0.69 & 0.51 & 0.79 & 0.6 \\
\hline Consumer Services (CS) & $\mathbf{0 . 4 8}$ & $\mathbf{2 . 6}$ & & & & & & 1 & 0.72 & 0.7 & 0.88 & 0.62 \\
\hline Telecommunications (T) & $\mathbf{0 . 3 3}$ & $\mathbf{2 . 6 2}$ & & & & & & & 1 & 0.66 & 0.82 & 0.57 \\
\hline Utilities (U) & $\mathbf{0 . 2 8}$ & $\mathbf{2 . 3 2}$ & & & & & & & & 1 & 0.67 & 0.45 \\
\hline Financials (F) & $\mathbf{0 . 4 8}$ & $\mathbf{3 . 0 9}$ & & & & & & & & & 1 & 0.67 \\
\hline Technology (TEC) & $\mathbf{0 . 2 7}$ & $\mathbf{4 . 2 7}$ & & & & & & & & & & 1 \\
\hline
\end{tabular}

Table 2 summarizes the performance of the five countries and ten industries during the period 2001 2011.

Panel A summarizes the monthly value-weighted country index returns. Panel B contains the summary statistics for the monthly returns on value-weighted industry portfolios. All returns and standard deviation are measured in US dollars and expressed in percentage per month. The correlations refer to value-weighted index returns. 
Panel A shows that there are substantial differences across markets both in terms of average returns and volatility of these returns. Singapore and Malaysia are among the poor performing countries, while Indonesia and Philippines are the highest performers. Measured by standard deviation of returns, Indonesian market is more than twice as volatile as Malaysian market. Panel B shows that industry performance is more varied than country performance. Utilities, Telecommunications, and Financials are among the lowest performing industries, while Basic Materials, Healthcare, and Consumer Goods are among the highest performing industries.

\section{Methodology}

In order to separate country performance from industry performance, we postulate the following model for the return on $i$-th security that belongs to industry $j$ and country $k$ (Heston and Rouwenhorst 1994) by,

$$
R_{i t}=\alpha_{t}+\beta_{j t}+\gamma_{k t}+\mathrm{e}_{i t}
$$

where $\alpha_{t}$ is a base level of return in period $t, \beta_{j t}$ is the industry effect, $\gamma_{k t}$ the country effect, and $e_{i t}$ is a firm-specific disturbance. Equation (1) allows separate influences of industry and country effects, but rules out any interaction between these effects. We assume that the firm-specific disturbances have a zero mean and finite variance for returns in all countries and industries, and are uncorrelated across firms. We have data on securities for five ASEAN countries, distributed over ten industry categories. As such, we code five country dummies and ten industry dummies. Defining an industry dummy $I_{i j}$ that is equal to one if security $i$ belongs to industry $j$ and zero otherwise, and a country dummy $C_{i k}$ that is equal to one if security $i$ belongs to country $k$ and zero otherwise for each period $t$, we can rewrite Equation (1) as:

$$
R_{i}=\alpha+\beta_{1} I_{i 1}+\beta_{2} I_{i 2}+\ldots \ldots+\beta_{10} I_{i 10}+\gamma_{1} C_{i 1}+\gamma_{2} C_{i 2}+\ldots \ldots+\gamma_{5} C_{i 5}+e_{i}
$$


Since each return belongs to one country and one industry, there is an identification problem if dummy variables are defined for every country and industry. To avoid the interpretation problem of an arbitrary benchmark, we impose the constraint that the sum of the industry coefficients equals zero and the sum of the country coefficients equals zero (Kennedy 1986). As such, we estimate Equation (2) is subject to the following restrictions:

$$
\begin{aligned}
& \sum_{j=1}^{10} n_{j} \beta_{j}=0 \\
& \sum_{k=1}^{5} m_{k} \gamma_{k}=0
\end{aligned}
$$

where $n_{j}$ and $m_{k}$ denote the value weights of firms in industry $j$ and country $k$, respectively. Most papers, including Heston and Rouwenhorst (1994), and Griffin and Karolyi (1998) show that imposing the restriction of Equation (3a) and (3b) not only prevent perfect multicollinearity among the regressors, but also allow this study to naturally interpret pure industry effect and pure country effect in Equation (2). Valueweighted least squares estimates for Equation (2) are computed each month subject to the restrictions in Equations (3a) and (3b). The monthly cross-sectional regressions yield a time series of the intercept, the country, and industry coefficients. We interpret the coefficients $\beta$ as the estimated pure industry effect relative to the value-weighted ASEAN market portfolio (i.e., the average returns of firms in an industry relative to firms located in the same country but belong to a different industry), and $\gamma$ as the estimated pure country effect relative to value-weighted ASEAN market portfolio (i.e., the average return of firms in a country relative to firms which are in the same industry but located in a different country).

\section{Results}

We compute monthly dollar-denominated returns for all firms from 2001 to 2011. Next, separate value-weighted regressions are run for the cross-section of firm returns 
every month and then we use the estimated coefficients to construct a time series of estimated $\gamma$ 's and $\beta$ 's. We decompose the value-weighted country index returns into a component common to all countries, the sum of industry effects based on the unique industrial composition, and the pure country specific component. In the case of Thailand (THAI), we can write $R_{\text {THAI }}$ as:

$$
R_{T H A I}=\hat{\alpha}+\sum_{j=1}^{10} x_{T H A I, j} \hat{\beta}_{j} I_{T H A I, j}+\hat{\gamma}_{T H A I}
$$

where $x_{T H A I, j}$ denotes the proportion of the total market capitalization of Thailand included in industry $j$. Equation (4) states that the return on Thailand country index differs from the return on ASEAN market portfolio due to two sources. First, the industrial composition in Thailand differs from that of ASEAN. For example, Thailand has higher proportions of consumer services and technology stocks relative to some of its ASEAN counterparts as it can be seen from Table 1, panel B. Second, the difference of the equity returns in Thailand compared to other countries in the same industry.

We can perform similar construction for industry index such as the Consumer Goods (CG) industry as follows:

$$
R_{C G}=\hat{\alpha}+\sum_{k=1}^{5} \phi_{k, C G} \hat{\gamma}_{j} C_{k, C G}+\hat{\beta}_{C G}
$$

where $\phi_{k, C G}$ denotes the proportion of the total market capitalization of consumer goods industry included in country $k$. Akin to country index, Equation (5) states that the return on the consumer goods index can differ from the return on the ASEAN market portfolio for two reasons. First, the country composition of the consumer goods industry differs from that of other industries. For example, consumer goods have a higher proportion of Malaysia stocks relative to other industries. Second, the difference of the equity returns in consumer goods compared to those in different industries but in the same country.

Note that by performing regression in Equation (2), we produce the industry and country effect for one specific month. More specifically, by conducting the crosssectional regression for every month, we could obtain a monthly time-series of pure-country effect and sum of industry effect from value weighted country index and calculate their variances. For example, in the case of value-weighted Thailand 
index in equation 4 , the pure-country effect is $\hat{\gamma}_{T H A I}$ and the sum of industry effect is $\sum_{j=1}^{10} x_{T H A I, j} \hat{\beta}_{j} I_{T H A I, j}$. In Table 3 , we calculate the time series variance of purecountry effect for Thailand using the following mathematical formula: Var (pure country effect $)=\operatorname{Var}\left(\hat{\gamma}_{\text {THAIt }}\right)$ where $t$ refers to the month of observation. Similarly, referring to Equation (4), the time series variance of sum of industry effect for Thailand is calculated using the formula: $\operatorname{Var}$ (sum of industry effect) $=$ Var $\left(\sum_{j=1}^{10} x_{T H A I t, j} \hat{\beta}_{j_{t}} I_{T H A I, j}\right)$.

Moreover, by performing cross-sectional regression for each month, we could also calculate a monthly time-series of pure-industry effect and sum of country effect from value-weighted industry index and obtain their variances. For instance, in the case of value-weighted Consumer Goods index in Equation (5), the pure-industry effect is $\hat{\beta}_{C G}$ and the sum of industry effect is $\sum_{k=1}^{5} \phi_{k, C G} \hat{\gamma}_{j} C_{k, C G}$. In Table 3 , we calculate the time series variance of pure-industry effect in Consumer Goods using the following mathematical formula: $\operatorname{Var}\left(\right.$ pure industry effect) $=\operatorname{Var}\left(\hat{\beta}_{C G t}\right)$, where $t$ refers to the month of observation. Similarly, referring to Equation (5), the time series variation of sum of country effect for Consumer Goods is calculated using this formula: Var (sum of country effect $)=\operatorname{Var}\left(\sum_{k=1}^{5} \phi, C G t \hat{\gamma}_{j t} C_{k, C G}\right)$.

Table 3 shows time-series variances of the pure country effects and the sum of industry effects component in value-weighted country index (panel A) as well as timeseries variances of the pure industry effects and the sum of country effects component in value-weighted industry index (panel B). 


\section{Table 3. Decomposition of Index Returns}

(US dollar denominated monthly returns)

\begin{tabular}{|l|c|c|c|c|}
\hline \multirow{2}{*}{ Panel A } & \multicolumn{2}{|c|}{ Pure Country Effect } & \multicolumn{2}{c|}{ Sum of Industry Effect } \\
\cline { 2 - 5 } & Variance & $\begin{array}{c}\text { Ratio relative } \\
\text { to ASEAN market }\end{array}$ & Variance & $\begin{array}{c}\text { Ratio relative } \\
\text { to ASEAN market }\end{array}$ \\
\hline Indonesia & 9.54 & 0.99 & 0.13 & 0.01 \\
Singapore & 1.05 & 1.02 & 0.02 & 0.01 \\
Malaysia & 2.03 & 0.94 & 0.03 & 0.01 \\
Philippines & 4.44 & 0.98 & 0.07 & 0.02 \\
Thailand & 3.37 & 1.01 & 0.04 & 0.01 \\
\hline Cross-country average & $\mathbf{4 . 0 8}$ & $\mathbf{0 . 9 9}$ & $\mathbf{0 . 0 6}$ & $\mathbf{0 . 0 1}$ \\
\hline Panel B & \multicolumn{2}{|c|}{ Pure Industry Effect } & Sum of Country Effects \\
\cline { 2 - 5 } & Variance & Ratio relative & Variance & Ratio relative \\
& to ASEAN market & & 0.23 & 0.09 \\
\hline Oil and Gas & 2.24 & 0.88 & 0.99 & 0.16 \\
Basic Materials & 4.66 & 0.75 & 0.05 & 0.08 \\
Industrials & 0.57 & 0.99 & 0.75 & 0.56 \\
Consumer Goods & 0.97 & 0.72 & 0.55 & 0.17 \\
Healthcare & 2.93 & 0.94 & 0.20 & 0.21 \\
Consumer Services & 0.75 & 0.80 & 0.13 & 0.06 \\
Telecommunications & 2.09 & 1.00 & 1.33 & 0.29 \\
Utilities & 2.39 & 0.52 & 0.03 & 0.09 \\
Financials & 0.30 & 0.81 & 0.13 & $\mathbf{0 . 1 8}$ \\
Technology & 7.81 & 0.85 & $\mathbf{0 . 8 3}$ & \\
\hline Cross-industry average & $\mathbf{2 . 4 7}$ & & & 0.13 \\
\hline
\end{tabular}

(Notes) (i) The pure country effect and the sum of industry effect in country indices are not uncorrelated. As a result, the variance ratios of pure country effect and sum of industry effect do not add up to one, due to the relatively small covariance between them.

(ii) Similarly, the pure industry effect and the sum of country effect in industry indices are not uncorrelated. As a result, the variance ratios of pure industry effect and sum of country effect do not add up to one, due to the relatively small covariance between them (Heston and Rouwenhorst 1994).

The table gives the variance of the components of the value-weighted country and monthly industry returns from Datastream Global equity indexes from March 2001 to August 2011. Each country index return is decomposed into a pure country effect and the sum of industry effect using the dummy variable regression methods. Each industry 
index return is similarly decomposed into a pure industry effect and the sum of country effect. The ratio relative to the market is the ratio of the variance of that component relative to the variance of the index return in excess of ASEAN market portfolio return. Following Griffin and Karolyi (1998, p. 362-363), variances are defined in \%-squared per month. For instance, in Panel A, the cross-country average can be expressed as $4.08 \%$-squared per month, equalling to 0.000408 per month.

The results in Panel A are useful for investors who invest in equity index of a particular ASEAN country. Specifically, investors would understand which effect provides greater contribution to the variance of value-weighted country return. For example, the result for Indonesia shows that the ratio of pure country effect relative to market (i.e., Indonesia equity index return minus ASEAN equity index return) is $99 \%$ and the ratio of sum of industry effect relative to market (i.e., Indonesia equity index return minus ASEAN equity index return) is $1 \%$. This suggests that most of the variation in value-weighted Indonesia index is due to the country effect. Indonesia is not an exception as, on average, Panel A shows that the sum of industry effect of ASEAN countries explains only $1 \%$ of the ASEAN country index variance compared to pure country effect of $99 \%$. This result is similar to Heston and Rouwenhorst (1994) paper who found that industrial structure explains very little (on average, 7.1\%) of the crosssectional difference in the 12 European countries between 1978 and 1992. In another paper, Griffin and Karolyi (1998) found that on average industrial structure only explain $2 \%$ of the cross-sectional difference in country return volatility across 25 countries and 66 industry classifications. Our result is also similar to Chen et al. (2006) who show sum of industry effect is on average $7 \%$ of country index return variance for developed markets while it is 1\% for emerging markets from January 1994 to May 2005.

The results in Panel B would be important for investors who invest in equity index of a particular industry in ASEAN. For example, the result for Oil and Gas shows that the ratio of pure industry effect relative to market (i.e., Oil and gas industry returns minus ASEAN equity index return) is $88 \%$ and the ratio of sum of country effect relative to market (i.e., Oil and gas industry returns minus ASEAN equity index return) is $9 \%$. This suggests that most of the variation in excess value-weighted Oil and Gas index of ASEAN market is mostly due to industry effect. On average, Panel B shows that the sum of country effects can only explain about $18 \%$ of the total industry index variance compared to pure industry effect which is $83 \%$. Again, this result is similar to Heston and Rouwenhorst (1994) paper who found that country structure explains very little (on average, $17.7 \%$ ) of the cross-sectional difference in country return volatility 
for the 12 European countries between 1978 and 1992. Our result is also similar to Chen et al. (2006) who showed sum of industry effects are on average $6 \%$ of country index return variance for developed markets, and 11\% for emerging markets from January 1994 to May 2005.

Moreover, Table 3 shows that, on average, the pure country effects $(\gamma, 4.08 \%$ squared) have greater variation than the pure industry effects $(\beta, 2.47 \%$-squared), suggesting that the variation of country effects is more important for explaining the return variation of ASEAN firms. This implies that in order to minimize their portfolio risk, investors should diversify their portfolio based on country selection rather than industry selection.

Table 4. Decomposition of Total Industry and Country Variance

\section{A. Country index components}

\begin{tabular}{|l|c|c|c|c|c|c|c|c|c|c|}
\hline \multirow{2}{*}{$\begin{array}{l}\text { Country } \\
\text { Indexes }\end{array}$} & \multicolumn{10}{c|}{$\begin{array}{c}\text { Ratio of each industry-specific variance } \\
\text { to total industry variance (\%) }\end{array}$} \\
\cline { 2 - 11 } & OG & BM & IND & CG & H & CS & T & U & F & TEC \\
\hline Indonesia & 0 & 14 & 1 & 39 & 0.1 & 0 & $\mathbf{4 1}$ & 0 & 6 & 0 \\
\hline Singapore & 6 & 0 & 13 & 4 & 0 & 9 & 32 & 0 & $\mathbf{3 5}$ & 0 \\
\hline Malaysia & 6 & 0 & 11 & 18 & 0 & 8 & 10 & $\mathbf{3 0}$ & 16 & 0 \\
\hline Philippines & 1 & 1 & 5 & 5 & 0 & 0 & $\mathbf{7 0}$ & 2 & 16 & 0 \\
\hline Thailand & 23 & 11 & 7 & 2 & 0.2 & 4 & 18 & 2 & $\mathbf{2 5}$ & 7 \\
\hline
\end{tabular}

(Note) (i) We highlight one industry with the highest ratio of each industry variance to total industry variance for each country.

(ii) OG: Oil and Gas, BM: Basic Materials, IND: Industrials, CG: Consumer Goods, H: Healthcare, CS: Consumer Services, T: Telecomnunications, U: Utilities, F: Financials, TEC: Technology 


\section{B. Industry index components}

\begin{tabular}{|l|c|c|c|c|c|}
\hline \multirow{2}{*}{ Industry Indexes } & \multicolumn{5}{|c|}{$\begin{array}{r}\text { Ratio of each country-specific variance } \\
\text { to total country variance (\%) }\end{array}$} \\
\cline { 2 - 6 } & Indonesia & Singapore & Malaysia & Philippines & Thailand \\
\hline Oil and Gas & 0 & 26 & 33 & 1 & $\mathbf{4 0}$ \\
\hline Basic Materials & $\mathbf{6 7}$ & 1 & 5 & 1 & 27 \\
\hline Industrials & 6 & $\mathbf{4 2}$ & 38 & 4 & 10 \\
\hline Consumer Goods & $\mathbf{7 6}$ & 3 & 19 & 2 & 1 \\
\hline Healthcare & $\mathbf{5 6}$ & 25 & 1 & 0 & 18 \\
\hline Consumer Services & 0 & $\mathbf{4 9}$ & 44 & 0 & 7 \\
\hline Telecommunications & $\mathbf{4 6}$ & 28 & 8 & 12 & 5 \\
\hline Utilities & 0 & 0 & $\mathbf{9 5}$ & 2 & 3 \\
\hline Financials & 12 & $\mathbf{4 8}$ & 21 & 5 & 13 \\
\hline Technology & 0 & 13 & 0 & 0 & $\mathbf{8 7}$ \\
\hline
\end{tabular}

(Note) We highlight one country with the highest ratio of each industry-specific variance to total industry variance for each industry.

Next, we seek to understand the contribution of each industry- $j$ to each of the ASEAN country- $k$ index. We calculate the ratio of the variance of each valueweighted pure industry effect $\left(\sigma^{2}\left(x_{k, j} \hat{\beta}_{j}\right)\right.$ to the total of industry effects variance $\left(\sum_{j=1}^{10}\left(\sigma^{2}\left(x_{k, j} \hat{\beta}_{j}\right)\right)\right.$ to measure the contribution. Table 4, Panel A shows, for Indonesia index, Telecommunications (41\%) contribute the most to the variance of equity returns. In Singapore, the main driver of total of industry effects variance is Financials (35\%). In Malaysia, the total of industry effect variance can be largely explained by Utilities (30\%). Philippines is mainly due to Telecommunications (70\%). Financials (25\%) dominated Thailand index. Lastly, it is worth noting that Oil and Gas, Basic Materials, Industrials, Consumer Goods, Healthcare, Consumer Services and Technology do not contribute significantly to any ASEAN country indexes.

We also present empirical results regarding the contribution of each country to each industry index. We calculate the ratio of the variance of each value-weighted pure country- $k$ effect $\left(\sigma^{2}\left(\phi_{k, j} \hat{\gamma}_{k}\right)\right.$ to the total of each industry- $j$ effects variance 
$\left(\sum_{k=1}^{5}\left(\sigma^{2}\left(\phi_{k, j} \hat{\gamma}_{k}\right)\right.\right.$ to measure the contribution. Table 4, Panel B provides ratios of individual country variance to total country variance for each value-weighted industry index. As Panel B shows, for Oil and Gas index, Thailand (40\%) contribute the most to the variance of equity returns. For Basic Materials, the main driver is Indonesia (67\%). For Industrials, the total industry effect variance can be largely explained by Thailand (42\%). Consumer Goods' total industry variance is mainly due to Indonesia $(76 \%)$. Moreover, Indonesia (56\%) dominated the total Healthcare index variance. Other than that, Singapore (49\%) is the main contributors for Consumer Services Index. Indonesia makes up $46 \%$ of the ratio of total country variance in Telecommunication index. For Utilities indexes, Malaysia (95\%) is important. For Financials, Thailand contributes $48 \%$. Moreover, Thailand $(87 \%)$ has provided the most contribution to Technology index. Overall, we find that Philippines is the only country that does not contribute significantly to any ASEAN industry indexes.

Cross referencing Panel A and Panel B of Table 4, we observe that there are three symmetric cases in which the main contributor of the industry component to country index and vice versa; viz., Indonesia and Telecommunications, Singapore and Financials, and Malaysia and Utilities. As Roll (1992), Heston and Rouwenhorst (1994), and Weiss (1998) pointed out, if industrial composition differs across countries, a particular country risk may be driven in part by a particular industry effect. In the context of ASEAN, investors who invest in Indonesia will be particularly affected by Telecommunications, Singapore by Financials, and Malaysia by Utilities. Symmetrically, if country composition differs across industries, a particular industry effect may be driven by a particular country effect. Again, in ASEAN, Telecommunications is particularly affected by Indonesia, Financials by Singapore, and Utilities by Malaysia.

We further investigate the trends of the relative importance between the country and the industry effect from year 2001 to 2011, using the rolling 12-month average variance presented in Figure 1. Figure 1 is useful for us to examine the effectiveness of ASEAN regional integration initiatives and the impact of economic shocks on ASEAN integration. 
Figure 1. Rolling 12-month Average of Pure Country and Industry Effect Variances

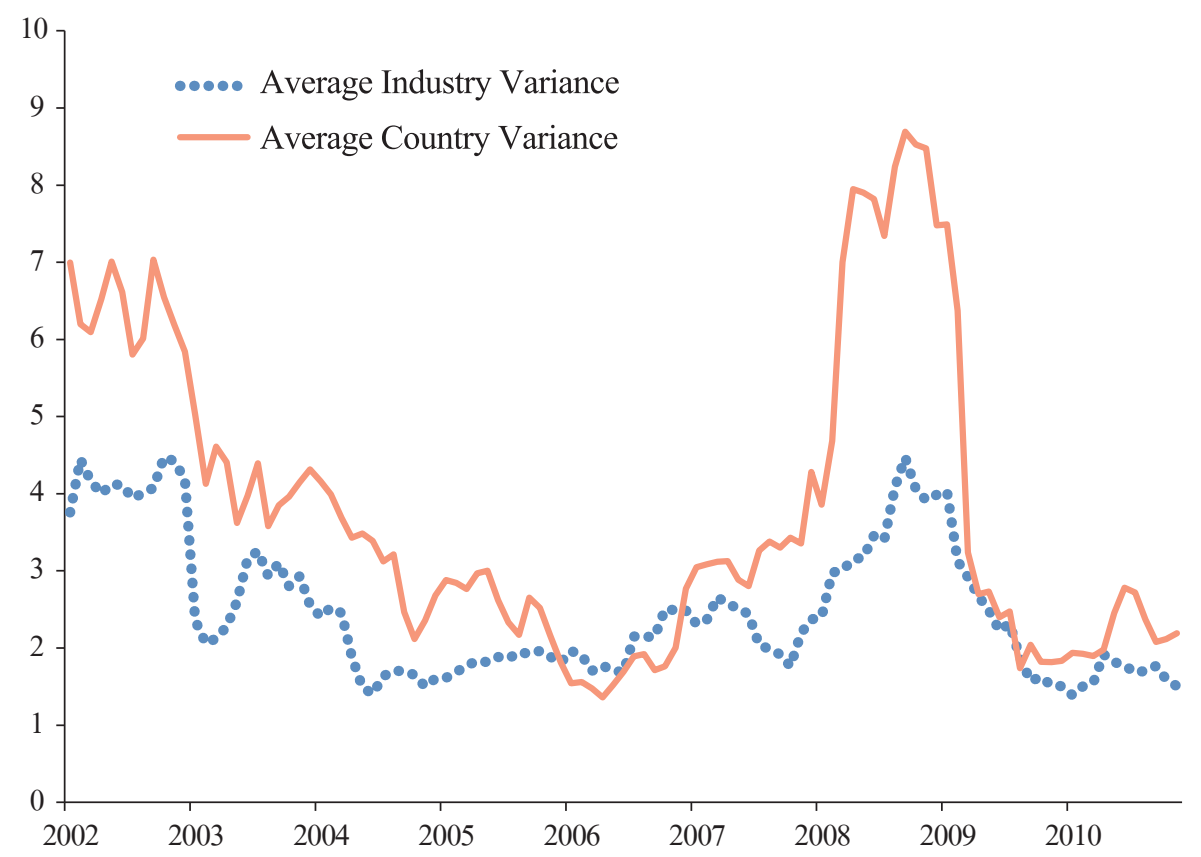

It is clear from Figure 1 that 12-month rolling average variance of the pure country and pure industry effect start declining from 2002 to 2006. According to Baca et al. (2000), the magnitude of the pure country and industry variance could inform whether a country or an industry becomes more segmented (increasing variance) or integrated (decreasing variance). Thus, the declining trends of the pure country and industry effect variance from 2002 to 2006 indicate that ASEAN countries and industries have increasingly been integrated over that period of time.

There were several initiatives to integrate the ASEAN economy during this period. First, the initiative of ASEAN Free Trade Area (AFTA) started since 1992 which aims at forming a single market and production base and it has met with the most success in the area of tariff liberalization. AFTA provided reduction or elimination of tariffs under a Common Effective Preferential Tariff (CEPT) scheme and the removal of quantitative restrictions and other Nontariff Measures (NTMs). Second, ASEAN Framework Agreements on Services (AFAS) started in 1995, aiming at enhancing cooperation in the service sectors among ASEAN countries by eliminating intra-regional trade 
restrictions and facilitate free flow of services by 2015. Third, ASEAN Investment Area (AIA) started since 1998. AIA aims to make ASEAN highly competitive in order to attract Forign Direct Investment (FDI) flows from ASEAN and non-ASEAN investors. Fourth, for the ASEAN Community in 2003, ASEAN leaders agreed to establish an ASEAN Economic Community (AEC) by 2020 (a goal that was subsequently accelerated to 2015) that consists of three pillars; political and security cooperation, economic cooperation, and socio-cultural cooperation. The ultimate goal of the AEC is the creation of a single market where there is free flow of goods, services, investments, capital, and skilled labor.

From Figure 1, we can further find that the country effect and the industry effect started to intersect and more or less exert the same magnitude of impact till the beginning of 2007. From 2007 to 2009, the country effect again started to dominate the industry effect in an upward trend with a wide gap. It, however, started to decline again after 2009 till 2011. The upward trends of both the country and the industry effect from 2007 to 2009 interestingly coincide with the outbreak of U.S. sub-prime crisis, suggesting that both ASEAN countries and its industries are affected by the crisisinduced shocks. The wide gap between the country and the industry effect suggests that the variance of equity returns seems to react more across countries than industries. This may not be surprising because the sudden swings in capital flows, abrupt adjustments in exchange rates, and a reversal in investors' risk attitude affect some countries more than others. The more open economies seem to have been hit harder, reflecting the global nature of the current crisis. For instance, Singapore suffered large negative output gaps. Their openness, with their financial markets closely tied to the global market, made the economy subject to a sharp contraction in external demand and a reversal in capital flows in the wake of the crisis. Malaysia and Thailand are also affected significantly by the global crisis. Both economies, however, have managed to recover rapidly on the back of strong economic fundamentals and relatively sound external positions.

Next, we examine the implications of the relative size of the pure country and the pure industry effect for portfolio diversification strategies in ASEAN. We investigate the effect of risk reduction if investors invest in ASEAN firms by (i) diversifying across countries but within specific industries (country diversification strategy), and (ii) diversifying across industries but within specific countries (industry diversification strategy) and (iii) diversifying across industries and countries (ASEAN diversification strategy).

Figure 2 shows the magnitude of portfolio variance as the number of equities in 
the portfolio increases, expressed as a percentage of the variance of a typical equity. The average equity return has a variance of 0.0028 per month. An equally-weighted portfolio of $N$ equities has a variance equal to $\frac{1}{n} \bar{\sigma}^{2}+\frac{n-1}{n} \overline{\operatorname{cov}}^{2}$. The average covariance in a large group of equities is just equal to the variance of an equally-weighted ASEAN index. When diversifying across all ASEAN equities, the average covariance is 0.00082 . This is $30.2 \%$ of the average variance of an individual equity. The weighted average variance of equally-weighted indices across countries is 0.000921 and the weighted average variance of equally-weighted indices across industry within single country 0.001097 . These numbers are $33.7 \%$ and $39.6 \%$ of the average security variances, respectively.

The top line of Figure 2 is the variance of a portfolio using country diversification strategy, the middle line represents industry diversification strategy, and the bottom line reflects ASEAN diversification strategy. Figure 2 shows that randomly combining ASEAN securities in large portfolios could reduce variance to $30.2 \%$ of the variance of the average security (bottom line). The investment strategy that diversifies across industries within a country reduces portfolio variance to $39.6 \%$ of the average equity variance (top line). The diversification across countries within a single industry, however, could reduce portfolio variance to $33.7 \%$ of the average equity variance (middle line). This means that the best diversification strategy is ASEAN diversification strategy, followed by country diversification strategy and the last, industry diversification strategy. 
Figure 2. Benefit of International Diversification through Portfolio Risk Reduction

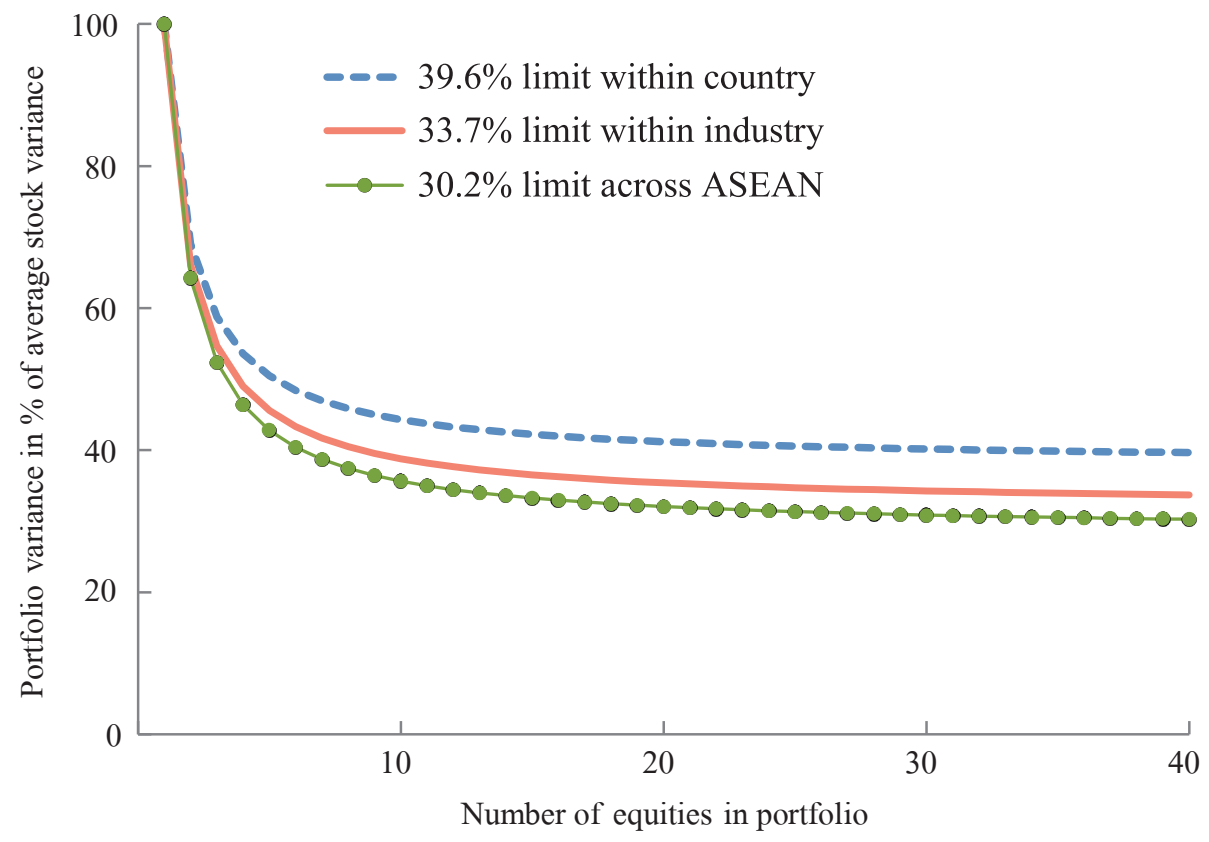

\section{Conclusions}

Using monthly data of 227 equities in ten industries and five ASEAN countries, this article employs a factor model to separate country and industry effects from equity returns. Our analysis shows that, on average, the pure country effects have greater variation than the pure industry effects, and are more important in explaining ASEAN firm equity return variance. The relative importance of the pure country and the pure industry effects changed over time. Before the sub-prime crisis, both effects show declining trends (more integrated). During the crisis period, both showed upward trends (less integrated) and started to diverge. After the peak of the crisis, both effects began to converge again in declining trends. Facing more integrated emerging markets in ASEAN, investors may find it more difficult to add value to equity portfolio through active equity allocation in the future.

We found that three industries, Telecommunications, Utilities, and Financials, 
contribute significantly to one or more ASEAN countries. Moreover, Philippines is the only country that does not have significant impact on any ASEAN industry index. Our results also show that there are three cases in which the main contributor of the industry component and that of the country index are symmetric (i.e., IndonesiaTelecommunications, Singapore-Financials, and Malaysia-Utilities).

Moreover, the result of this article also suggests that portfolio managers should put their diversified ASEAN portfolio based on the country effects.

Received 5 December 2013, Revised 20 March 2014, Accepted 10 June 2014

\section{References}

Ammer, J., Mei, J. (1996), "Measuring international economic linkages with stock market data", Journal of Finance 51 (5), 1743-1763.

Anderson, Christopher W., Fedenia, Mark, Hirschey, Mark, Skiba, Hilla. (2011), "Cultural influences on home bias and international diversification by institutional investors", Journal of Banking \& Finance 35, 916-934.

Baca, Sean P., Brian L. Garbe, and Richard A. Weiss. (2000), "The rise of sector effects in major equity markets," Financial Analysts Journal, 56, 35-40.

Bekaert, Geert, and Campbell R. Harvey. (1995), “Time-varying world market integration", Journal of Finance, 50, 403-443.

Bekaert, Geert, and Campbell R. Harvey. (1997), "Emerging equity market volatility", Journal of Financial Economics, 43, 29-77.

Bekaert, Geert, and Campbell R. Harvey. (2000), "Foreign speculators and emerging equity markets", Journal of Finance, 55, 565-614.

Bekaert, Geert, Campbell R. Harvey, and Christian Lundblad. (2001), "Emerging equity markets and economic development", Journal of Development Economics, 66, 465-504.

Bekaert, Geert, Robert J. Hodrick, and Xiaoyan Zhang. (2009), “International stock 
return comovements", The Journal of Finance 64, no. 6 (2009), 2591-2626.

Cavaglia, Stefano, Christopher Brightman, and Michael Aked. (2000), "The increasing importance of industry factors", Financial Analysts Journal, 56, 41-54.

Chan, Kalok, Covrig, Vicentiu, Ng, Lilian. (2005), "What determines the domestic bias and foreign bias? Evidence from mutual fund equity allocations worldwide", Journal of Finance 60, 1495-1534.

Chen, Jianguo, Andrea Bennett, and Ting Zheng. (2006), "Sector effects in developed vs. emerging markets", Financial Analysts Journal, 62, 40-51.

Cooper, Ian, and Evi Kaplanis. (1994), "Home bias in equity portfolios, inflation hedging, and International Capital Market Equilibrium”, Review of Financial Studies, vol. 7, no. 1 (Spring):45-6

Eiling, Esther, Bruno Gerard, Pierre Hillion, and Frans A. de Roon. (2012), "International portfolio diversification: Currency, industry and country effects revisited", Journal of International Money and Finance 31, no. 5, 1249-1278.

Eun, Cheol S., and Jinsoo Lee. (2010), "Mean-variance convergence around the world", Journal of Banking \& Finance 34, no. 4, 856-870.

Fedenia, Mark, Sherrill Shafer, and Hilla Skiba., (2013), "Information immobility, industry concentration, and institutional investors' performance", Journal of Banking \& Finance 37, no. 6, 2140-2159.

Ferreira, Miguel A., and Paulo M. Gama. (2005), "Have world, country, and industry risks changed over time? An investigation of the volatility of developed stock markets", Journal of Financial and Quantitative Analysis 40, no. 01, 195-222.

Flavin, Thomas J. (2004), "The effect of the Euro on country versus industry portfolio diversification", Journal of International Money and Finance 23, no. 7, 1137-1158.

French, Kenneth R., Poterba, James M. (1991), "Investor diversification and international equity markets," American Economic Review 81, 222-226.

Griffin, John M., and G. Andrew Karolyi. (1998), "Another look at the role of the industrial structure of markets for international diversification strategies," Journal of financial economics 50, no. 3, 351-373.

Grubel, Herbert G. (1968), "Internationally diversified portfolios: Welfare gains and 
capital flows", American Economic Review, 58, 129991314.

Harvey, Campbell R. (1995), "Predictable risk and returns in emerging market", The Review of Financial Studies, 8, 773-816.

Heston, Steven L., and K. Geert Rouwenhorst. (1994), "Does industrial structure explain the benefits of international diversification?", Journal of Financial Economics, 36, 3-27.

Karolyi, G.A., Stulz, R.M. (1996), "Why do markets move together? An investigation of US_Japan stock return comovements", Journal of Finance 51 (3), 951-986.

Kennedy, Peter. (1986), "Interpreting dummy variables", Review of Economics and Statistics, 68, 174-175.

Lessard, Donald R. (1974), "World, national and industry factors in equity returns", Journal of Finance, 29, 379-391.

Leuz, Christian, Lins, Karl V., Warnock, Francis E. (2010), "Do foreigners invest less in poorly governed firms?", Review of Financial Studies 23, 3245-3285.

Levy, Haim, and Marshall Sarnat. (1970), "International diversification of investment portfolios", American Economic Review, 60, 6688675.

Marcelo, José Luis Miralles, José Luis Miralles Quirós, and José Luís Martins., (2013), "The role of country and industry factors during volatile times", Journal of International Financial Markets, Institutions and Money 26, 273-290.

Roll, Richard. (1992), "Industrial structure and the comparative behavior of international stock market indices", Journal of Finance, 47, 3-42.

Solnik, Bruno H. (1974), "Why not diversify internationally rather than domestically?", Financial Analyst Journal 30, 48-54.

Tesar, Linda, and Ingrid Werner. (1995), "Home bias and high tumover", Journal of International Money and Finance, vol. 14, no. 4 (August):467-492.

Weiss, Richard A. (1998), "Global sector rotation: new look at an old idea”, Financial Analysts Journal, 54, 6-8 